\title{
STUDY OF MEMBERS OF DIFFERENT TRIBES OF FAMILY ASTERACEAE WITH REFERENCE TO STEM ANATOMY
}

\author{
P. K. Tete* and A. A. Fulzele \\ Shri Mathuradas Mohota College of Science, Nagpur - 440009 (M.S.) \\ *Corresponding Author: pawantete10@gmail.com \\ Communicated : 01.01.19 \\ Revision : $11.01 .2020 \&$ \\ 18.01 .2020 \\ Published: 30.01 .2020 \\ Accepted : 28.01.2020
}

\begin{abstract}
:
Asteraceae is one of the widest family in Angiosperms having significant economic values, such as production of oil, ornamental plant, secondary metabolites, etc. In family Asteraceae about 1,535 genera distributed in 13 tribes. The current work aims at studying the differences in stem anatomy and floral characters of these tribes. In the present study sixteen species belonging to ten tribes were documented, The Heliantheae, one of the tribes' in this family is more dominant in Nagpur region, and in the present study six genera were recorded. This was followed by two genera in Cichorieae, and one genus each in the tribes Anthemideae, Astereae, Echinopeae, Eupatorieae, Gnaphalieae, Inuleae, Mutisieae and Vernonieae. Detailed study of the arrangement of vascular bundles and type of trichomes found on the stem was studied using free hand-sections. For the floral characters, ray floret, disk floret, shape of receptacle and the type of capitulum inflorescence was studied. An attempt was made for the development of a taxonomical key based on stem anatomical features highlighting the differences in the tribes. Microphotography of the floral components and anatomical study of the stem of these plants, revealed characters which are uutilized for creating a key for various tribes based on morphology as well as anatomical characters.
\end{abstract}

Key words: - Asteraceae, tribes, Heliantheae, stem anatomy, capitulum, key

\section{INTRODUCTION:}

The family Asteraceae also called the Compositae has been considered to be a unified evolutionary by all botanists. This family is one of the largest of the eudicots with over 32,000 species and at least 1,900 genera in 13 subfamilies (The Plant List, 2013) Members of the family Asteraceae can be found all over the world. These plants have evolved many adaptations to withstand harsh environment as well as more moderate climates.

Many plants in the family Asteraceae are economically important as weed, ornamentals, medicinal and green vegetables are poisonous plants. Commercially the flowers of this family are very famous of their colorful florets. A wide range of horticultural species are grown in home garden or national garden plots. The Asteraceae feature extensively in gardens distributed throughout the world as ornamental. A wide range of horticultural species is grown both under grass, and as herbaceous garden plants throughout the world. About half the species of Asteraceae are native to the Old World and half to the New World.

TRIBE is a taxonomic group that is a subdivision of a subfamily

The Asteraceae consist of 1528 genera and 22,750 species. The Asteraceae has recently been classified into at least ten subfamilies and members of the family have a worldwide distributed. ( Ngu Wah Win, 2018)

This family includes tribes - Vernonieae, Eupatorieae, Asteroideae, Inuloideae, Helianthoideae, Antemideae, Senecioideae, Calendulaceae, Cynaroideae, Mutisiaceae, and Cichoriaceae. (Hooker, 1881) As per Cronquist (1981), in Asteraceae 13 tribes found. In bestknown family of flowering plants, the Asteraceae may be organized into 3 subfamilies: (1) the 
Brandesiodieae with a single tribe, (2) the Cichorioideae with 6 tribes, and (3) the Asteroideae with 7 tribes. (Heywood et al.1978). Family of Asteraceae is common at temperate region, In India, Asteraceae is dominant towards Himalayan regions, nearly 955 taxa are found, (72.67\%) with about 202 taxa of which are endemic to the India. The chef center of diversity of the Indian Asteraceae is due to conducive temperature and altitudes, habitats distributed from the cold deserts of Ladakh to forests of north-east India.

The works were carried out in Nagpur region were detailed study of the arrangement of vascular bundles and type of trichomes found on the stem was studied by taking free hand-sections. For the floral characters, ray floret, disk floret, shape of receptacle and the type of capitulum inflorescence was studied. An attempt was made for the development of a key based on stem anatomical features highlighting the differences in the tribes. Microphotography of the floral components and anatomical study of the stem of these plants, revealed characters which can be utilized for creating a key for various tribes based on morphology as well as anatomical characters.

\section{MATERIAL \& METHODS}

The species belonging to different tribes of Asteraceae were collected from Nagpur region. Field notes were made of precise location and of habitat of that plants type. They were record and take photographs in the field. After the collection, the vegetative and floral parts of fresh specimens were studied for taxonomic characters; some of collected specimens were dried and pressed to prepared herbarium sheet.

The collected specimens were preserving for further anatomical study. For anatomical study, the fresh and preserve specimens were examining by preparing free-hand section for microscopic study of stem. These sections were stained with double staining technique and observed under microscope for anatomical characters.

On the basis of anatomical character bracketed key prepared.

Observations and Results

The works were carried out in Nagpur region were detailed study of the arrangement of vascular bundles and type of trichomes found on the stem was studied for the following tribes given in the table no. 1. \& table No. 2 shows important character identified along with anatomical feature in front of respective names of the plant studied.

\section{RESULT \& DISCUSSION}

The works were carried out in Nagpur region were detailed study of the arrangement of vascular bundles and type of trichomes found on the stem was studied for the following tribes given in the table no. 1. \& table No. 2 shows important character identified along with anatomical feature in front of respective names of the plant studied.

\subsection{KEY TO ANATOMICAL CHARECTERS OF TRIBES OF DIFFERENT GANERA FROM ASTERACEAE}

1. Secretary canal

Cosmos sulphureus Tribe HELIANTHEAE

1. Secretary canal absent

2. Epidermis with Bitrunket trichomes Vernonia cineria Tribe

VERNONIEAE

2. Epidermis with other trichomes

3. Long blunt trichome

Gerbera jamesonii Tribe

\section{MUTISIEAE}

3. Long pointed trichome

4. Epidermis spiny

Ageratum conyzoides Tribe EUPATORIEAE 
4. Epidermis non spiny

5. Biseriate multicellular trichome

\section{ECHINOPEAE}

Echinops echinatus Tribe

5. Uniseriate multicellular trichome

6. Secretary trichome Blumea lacera Tribe

INULEAE

6. Non secretary trichome

.... (7)

7. Small and big vascular bundle alternate Solidago canadensis Tribe

ASTEREAE

7. Same sized vascular bundle

8. Pericycle oval rounded

Launaea procumbens Tribe

CICHORIEAE

8. Pericycle non oval

9. Secondary growth shown

\section{ANTHEMIDEAE}

Chrysanthemum sp Tribe

9. Many seriate vessels

............Gnomophilum palustre Tribe

GNAPHALIEAE

3.2. KEY TO ANATOMICAL CHARACTERS DIFFENT GENERA

1. Stem cylindrical.

1. Stem angular.

2. Cortex with secretory canal

Cosmos sulphureus

2. Cortex without secretory canal. (3)

3. Epidermis with blunt trichome

\section{Parthenium hysterophorus}

3. Epidermis with trunket trichome.

Vernonia cineria

3. Epidermis without trichome...

Sonchus oleraceus
4. Spiny cuticle conyzoides

4. No spiny cuticle

5. Bisereate multicellular trichome

Echinops echinatus

5. Unisereate multicellular trichome and others (6)

6.

Arenchymatous cortex Eclipta alba

6. Non Arenchymatous cortex.

(7)

7. Secretory trichome.

7. Non secretory trichome.

8. Small and big vascular bundle alternate.

Solidago canadensis

8. Small and big vascular bundle alternate with conical

V.B......

\section{Gerbera jamesonii}

8. Same size V. B. Blumea lacera

9. Pericycle hemispherical, sub rounded.

Xanthium indicum

9. Pericycle non hemispherical. (10)

10. Pericycle oval or rounded.

Launaea procumbens

10. Pericycle non oval or non rounded

11. Long elongated tapering trichome

11. Non elongated tapering trichome (13)

12. Secondary growth

12. Non secondary growth

Chrysanthemum sp.

13. Many seriate vessels

Synedrella nodiflora

13. Big vessels

Gnomophilum palustre

Tridex procumbens

\section{Conclusion}

Morphological details of 16 species carried out belonging to10 tribes. Tribe HELIANTHEAE is common in Nagpur region, 6 species were collected and described.

On the bases of anatomical characters different tribes can be distinguish, for example, Anatomical characters of tribes and genera is given in the Table No. 3. Thus anatomical features can be included for identification of different tribes in Asteraceae. Looking to the diversity of family Asteraceae more detailed work is required.

ACKNOWLEDGEMENT: - We are very grateful to the principal of Shri Mathuradas Mohota College of Science, Nagpur for providing necessary facilities required for work. 


\section{REFERENCES}

Cronquist, A. (1981). An Integrated System of Classification of Flowering Plants. Columbia University Press, New York.

Funk V. A; Susanna A; T. Stuessy and Robinson.

H. E. (2009). Classification of Compositae. Book. Systematic, Evolution and Biogeography of Compositae. Pub. IAPT, Vienna. Edt. V.

A. Funk, A. Susanna, T. Stuessy. R. Bayer, pp 171-189.

Heywood V. H. (1978) Flora Europaea: Notulae Systematicae ad Floram Europaeama spectantes.

Kandemir A; Makbul S, Turkmen Z, Yilmaz M. (2006). Morphological, Anatomical and Palynological Investigation on Sonchus erzincanicus Matthews (Asteraceae) Turkish Journal of Botany 30 (5): 405411.

Mitra Sunit, S. K. Mukherjee. (2017) Plant biodiversity: monitoring, assessment and conservation. Department of Botany, Ranaghat College, Nadia - 741 201, West Bengal, India. DOI$10.1079 / 9781780646947.0036$

Ngu Wah Win. (2016). Anatomical study on Tridax procumbens L. from Tribe Heliantheae.

http://www.academia.edu p. 1-26

Rahman. A.H.M. M.. (2008). Taxonomic Studies on the Family Asteraceae (Compositae) of the Rajshahi Division.
Research Journal of Agriculture and Biological Sciences, 4(2): 134-140.

Rob H. and Brenandendron D (2017). Anatomical Studies on the Stem and Leaf of Vernonia amygdalina Del, Cyanthillium cinereum (L.) Journal of Applied Life Sciences International 15(4): $1-8$

Roque Nádia, David J. Keil and Alfonso Susanna. (). Apendix A: Illustrated glossary of Compositae, www.alcb.ibio.ufba.br

Shi, Z. et al. [total: 33 co-authors]. (2011). Asteraceae (Compositae) [family introduction,glossary, systematic list, and key to tribes]. Wu, Z. Y., Raven, P. H. \& Hong, D. Y., eds., Flora of China Volume 20-21 (Asteraceae). Science Press (Beijing) \& Missouri Botanical Garden Press (St. Louis).

http://efloraindia.nic.in/efloraindia/searchTaxo n.action (Botanical survey of India/ Flora Of India)

The Plant List (2013). Version 1.1. Published on the Internet; http://www.theplantlist.org (accessed 1st January). 


\begin{tabular}{|c|c|c|}
\hline \multicolumn{3}{|c|}{$\begin{array}{c}\text { Table No. 1. Number of tribes and genus of family } \\
\text { Asteraceae described from Nagpur region }\end{array}$} \\
\hline $\begin{array}{c}\text { Sr. } \\
\text { No. }\end{array}$ & $\begin{array}{c}\text { Name of plant genera } \\
\text { studied }\end{array}$ & $\begin{array}{c}\text { Name of tribes } \\
\text { studied }\end{array}$ \\
\hline 1 & Gerbera jamesonii & MUTISIEAE \\
\hline 2 & Echinops echinatus & ECHINOPEAE \\
\hline 3 & Launaea procumbens & CICHORIEAE \\
\hline 4 & Sonchus oleraceus & CICHORIEAE \\
\hline 5 & Vernonia cineria & VERNONIEAE \\
\hline 6 & Solidago canadensis & ASTEREAE \\
\hline 7 & Chrysanthemum sp. & ANTHEMIDEAE \\
\hline 8 & Gnomophilum palustre & GNAPHALIEAE \\
\hline 9 & Blumea lacera & INULEAE \\
\hline 10 & Cosmos sulphureus & HELIANTHEAE \\
\hline 11 & Synedrella nodiflora & HELIANTHEAE \\
\hline 12 & Tridex procumbens & HELIANTHEAE \\
\hline 13 & Xanthium indicum & HELIANTHEAE \\
\hline 14 & Eclipta alba & HELIANTHEAE \\
\hline 15 & Parthenium hysterophorus & HELIANTHEAE \\
\hline 16 & Ageratum conyzoides & EUPATORIEAE \\
\hline
\end{tabular}

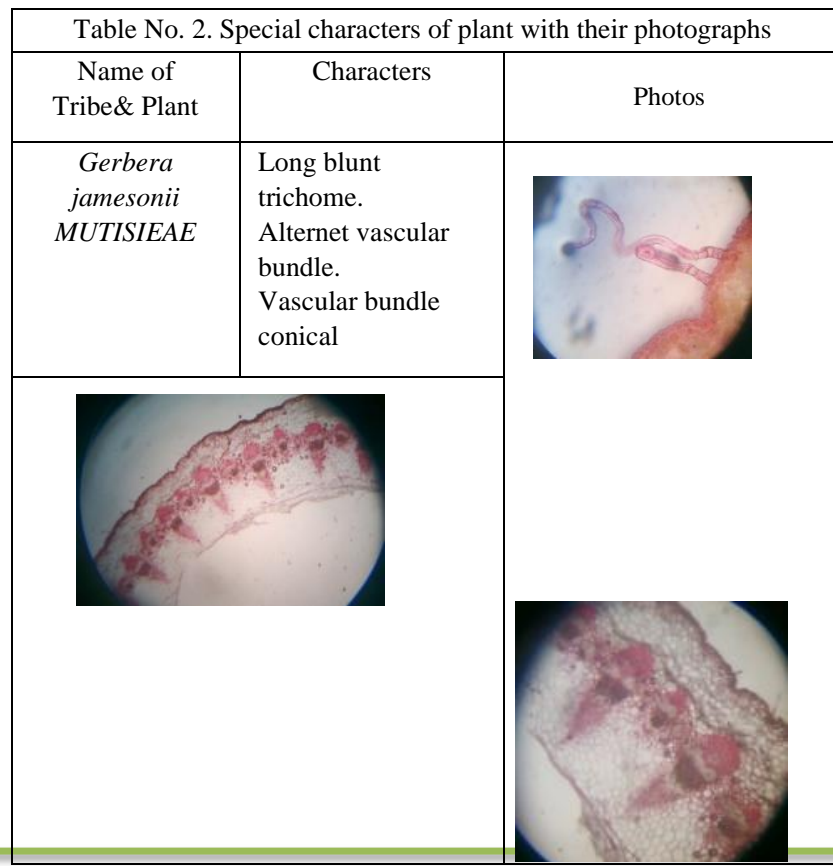


I J R B A T, Issue (VIII), Vol. I, Jan 2020: 161-173

A Double Blind Peer Reviewed Journal

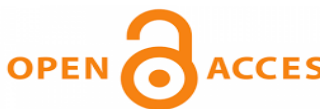

e-ISSN 2347 - 517X

Original Article

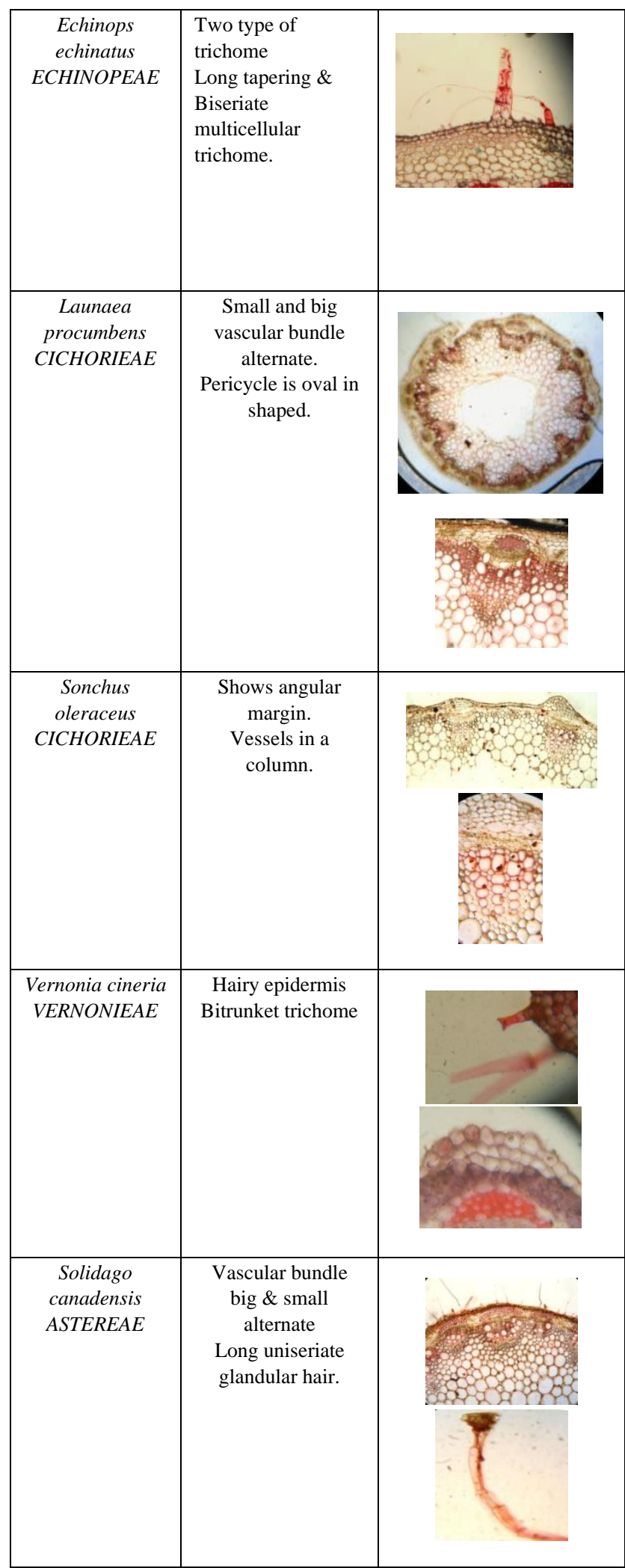


I J R B A T, Issue (VIII), Vol. I, Jan 2020: 161-173

A Double Blind Peer Reviewed Journal

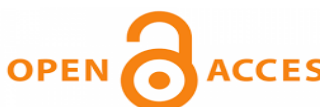

e-ISSN $2347-517 X$

Original Article

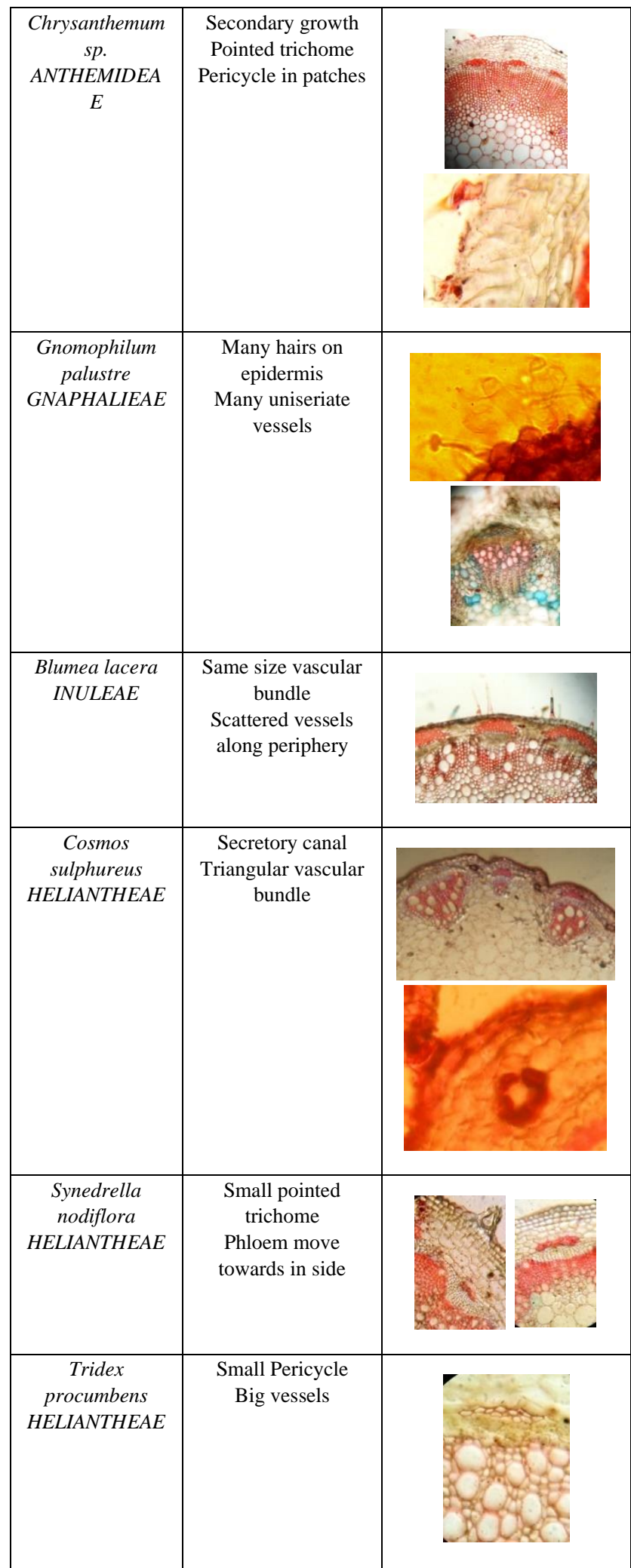


I J R B A T, Issue (VIII), Vol. I, Jan 2020: 161-173

A Double Blind Peer Reviewed Journal

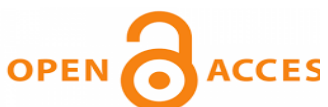

e-ISSN $2347-517 X$

Original Article

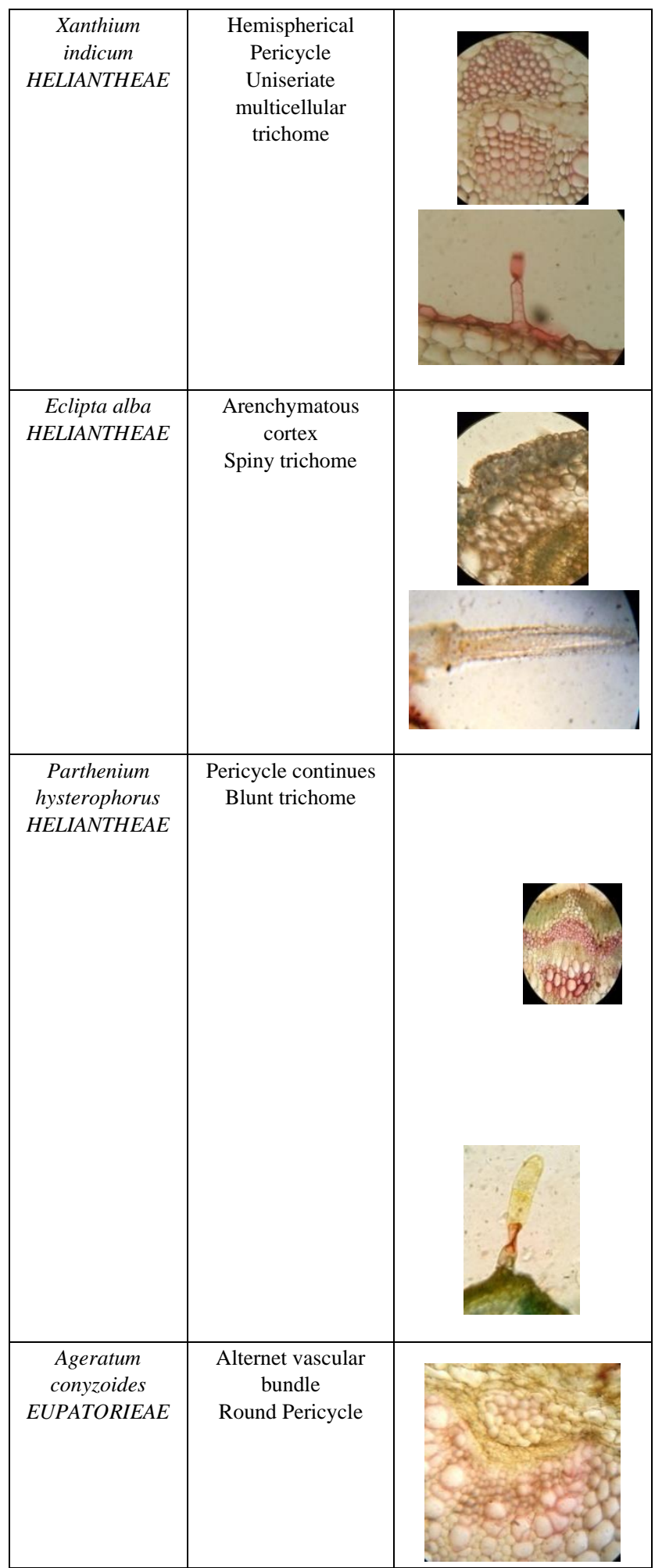


I J R B A T, Issue (VIII), Vol. I, Jan 2020: 161-173

A Double Blind Peer Reviewed Journal

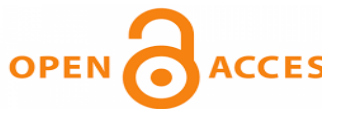

open $\bigcirc$ Acces
e-ISSN $2347-517 X$

Original Article
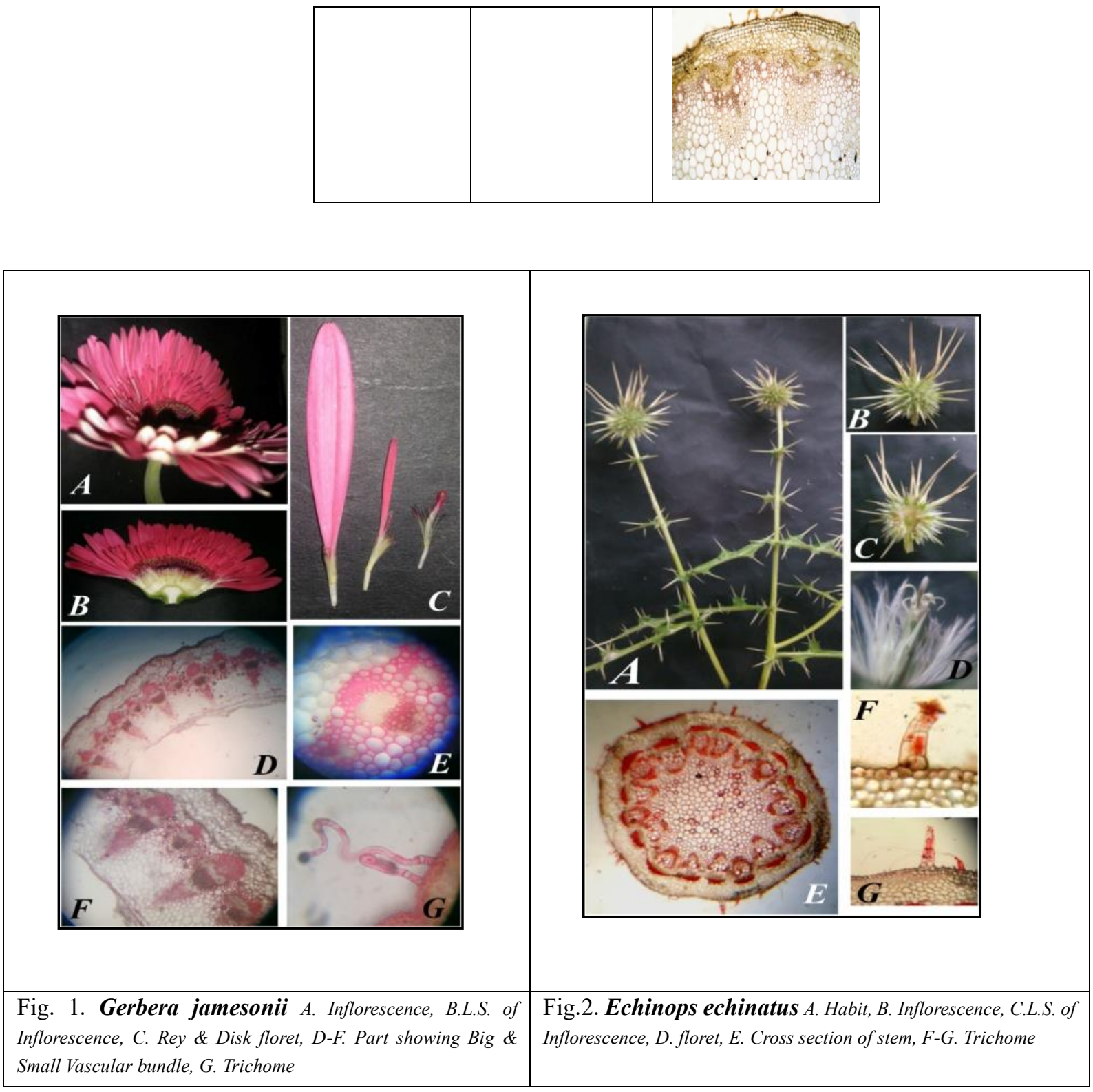
I J R B A T, Issue (VIII), Vol. I, Jan 2020: 161-173

A Double Blind Peer Reviewed Journal

OPEN $\bigcirc$ ACCES

e-ISSN 2347 - 517X

Original Article

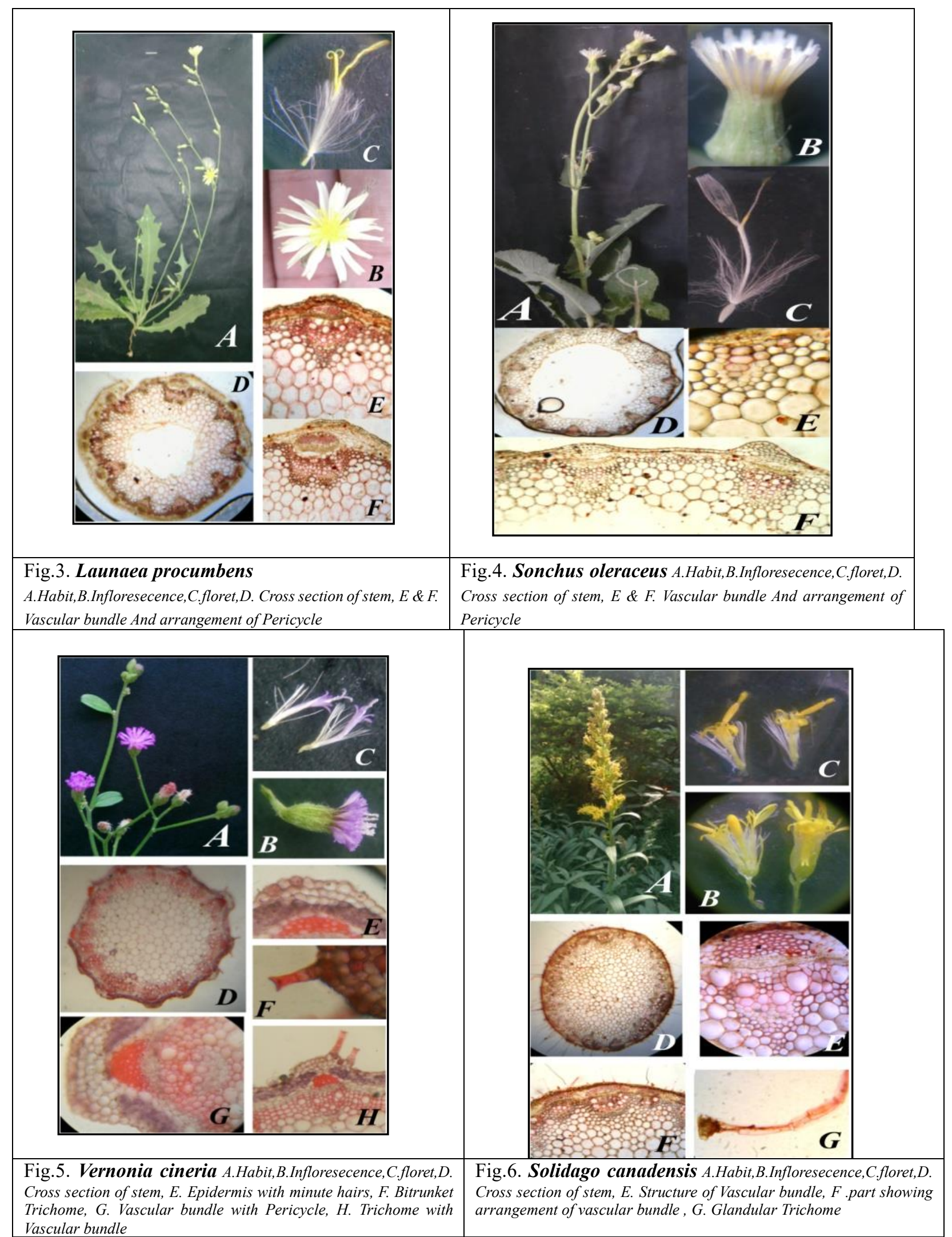

Fig.4. Sonchus oleraceus A.Habit,B.Infloresecence, C.floret, $D$. Cross section of stem, $E \&$ \& Vascular bundle And arrangement of Pericycle 
I J R B A T, Issue (VIII), Vol. I, Jan 2020: 161-173

A Double Blind Peer Reviewed Journal

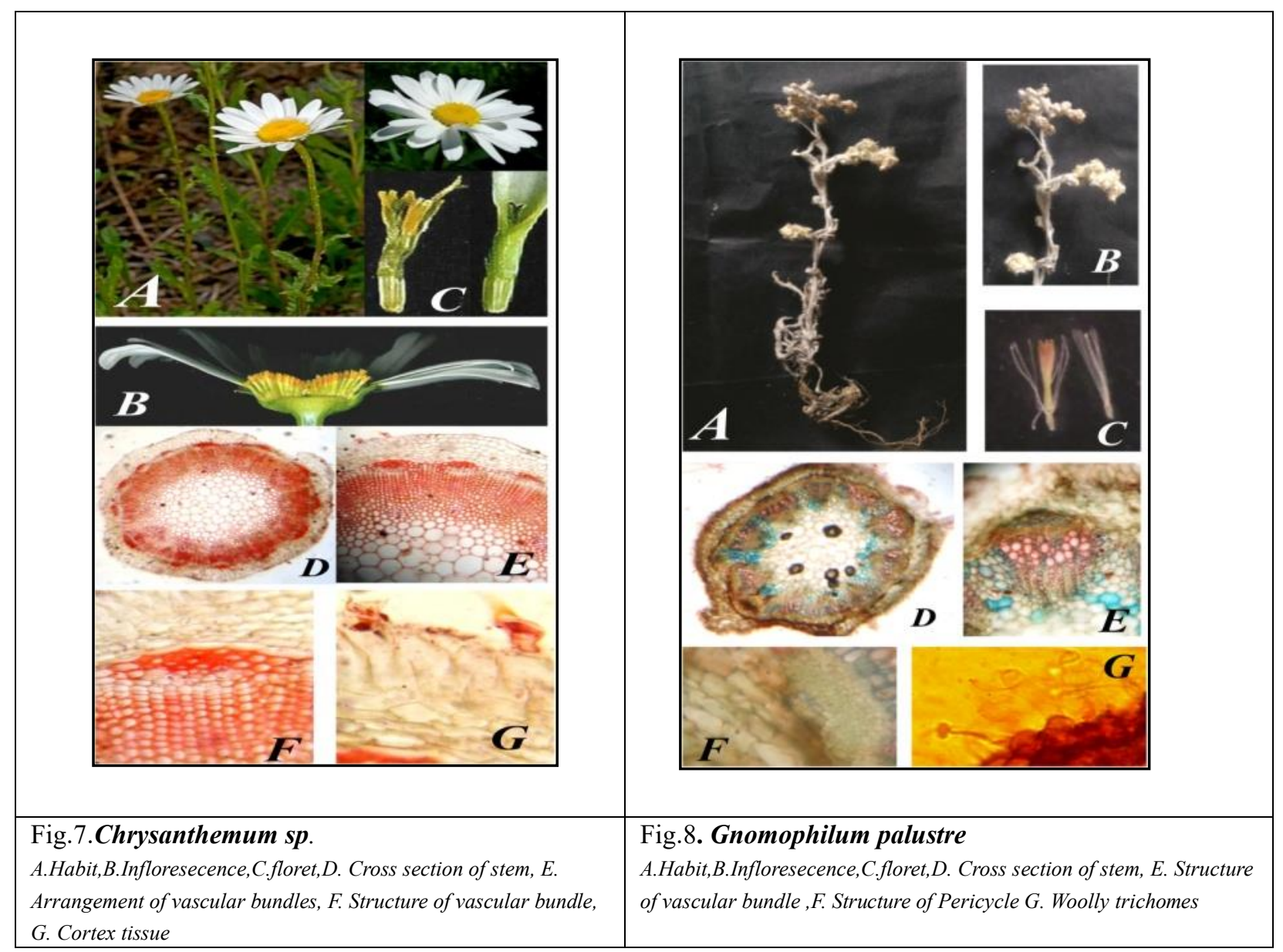


I J R B A T, Issue (VIII), Vol. I, Jan 2020: 161-173

A Double Blind Peer Reviewed Journal

OPEN $\bigcirc$ ACCES

e-ISSN $2347-517 X$

Original Article
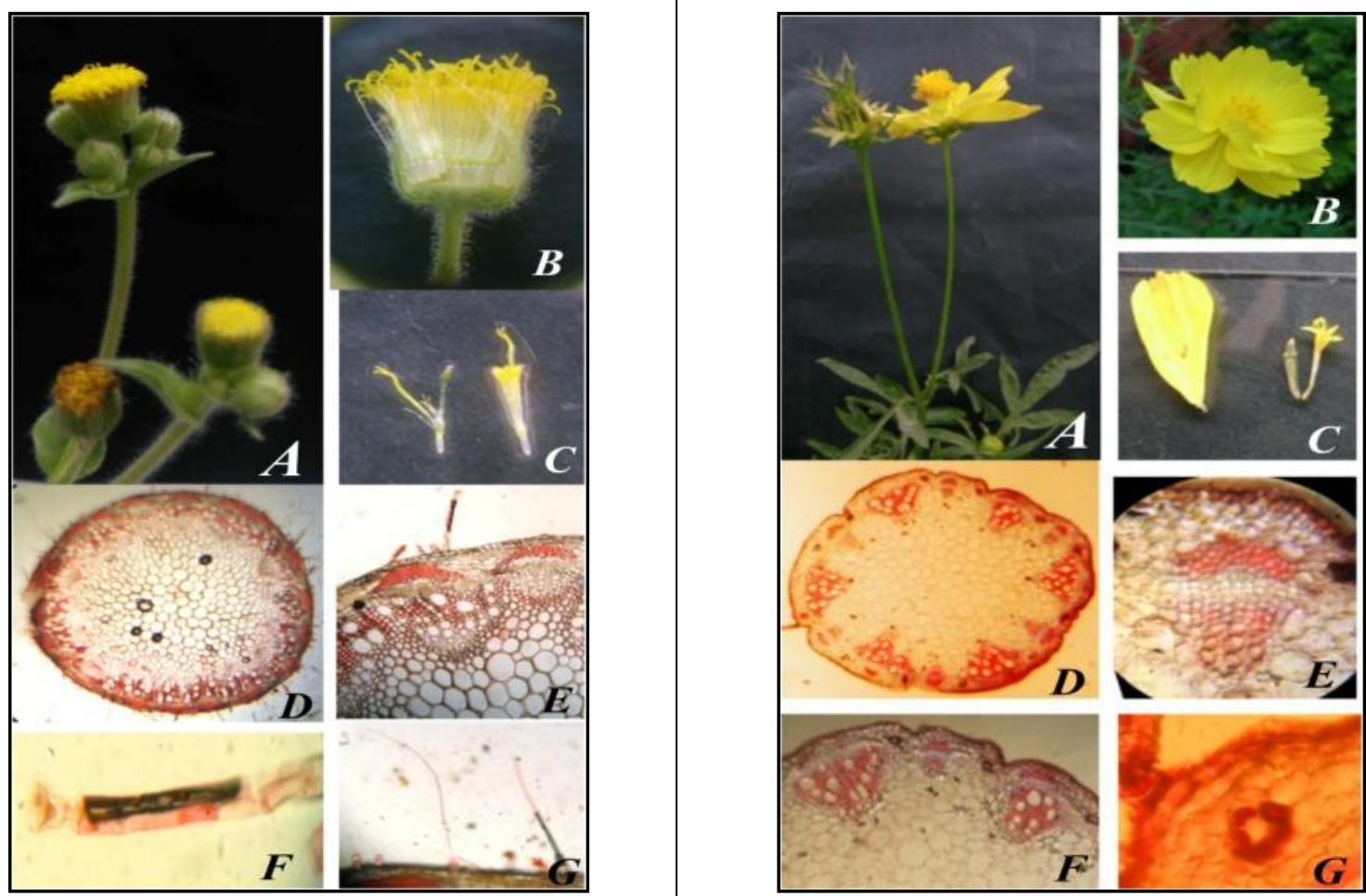

Fig.9. Blumea lacera

A. Habit, B.L.S. of Inflorescence, C. floret, D. Cross section of stem, E. Arrangement of vascular bundles, F. Structure of Glandular trichome, G. Tapering trichome

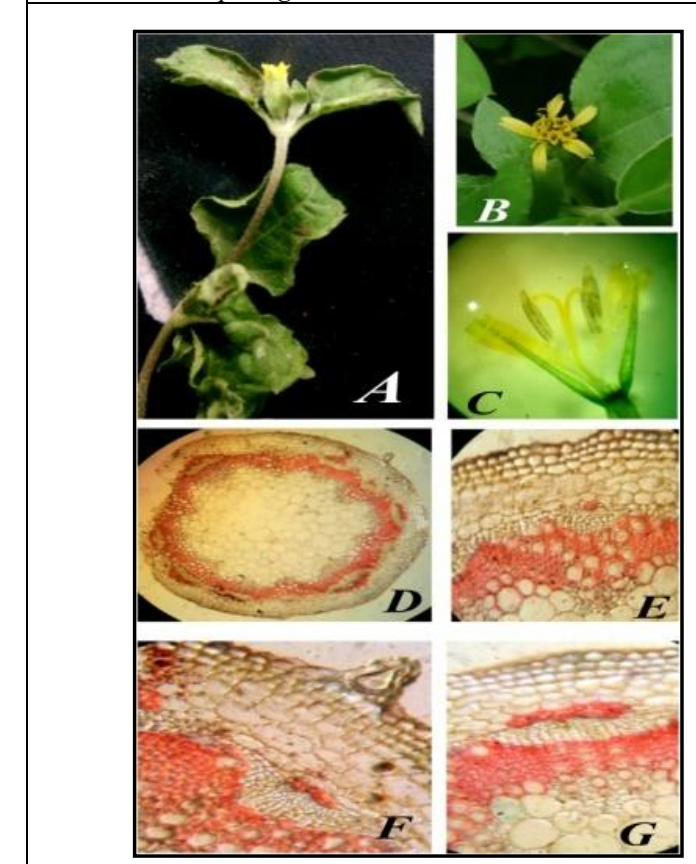

Fig.11. Synedrella nodiflora

A. Habit, B. Inflorescence, C .floret, D. Cross section of stem, E. Vascular bundles, F. Small trichome with cortex and Pericycle, G.

Structure of Pericycle
Fig.10. Cosmos sulphureus A.Habit,B.Infloresecence, C.floret,D. Cross section of stem, E. Structure of vascular bundle, F. Arrangement of vascular bundles, $G$. Cortex showing canal

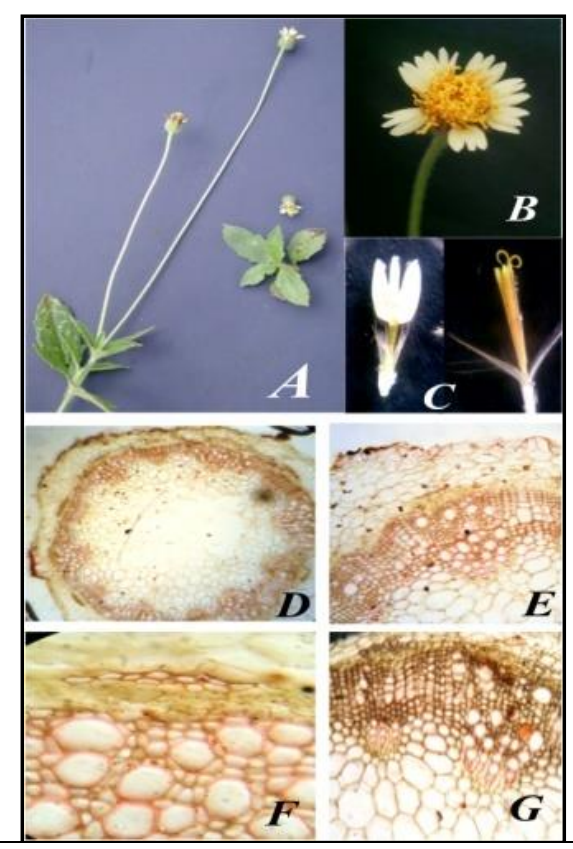

Fig.12. Tridex procumbens

A. Habit, B. Inflorescence, C, floret, D. Cross section of stem, E. Cortex \& vascular structure, F. Structure of Pericycle and xylem vessels, G. Arrangement of vascular bundles. 
I J R B A T, Issue (VIII), Vol. I, Jan 2020: 161-173

A Double Blind Peer Reviewed Journal

OPEN $\bigcirc$ ACCES

e-ISSN $2347-517 X$

Original Article

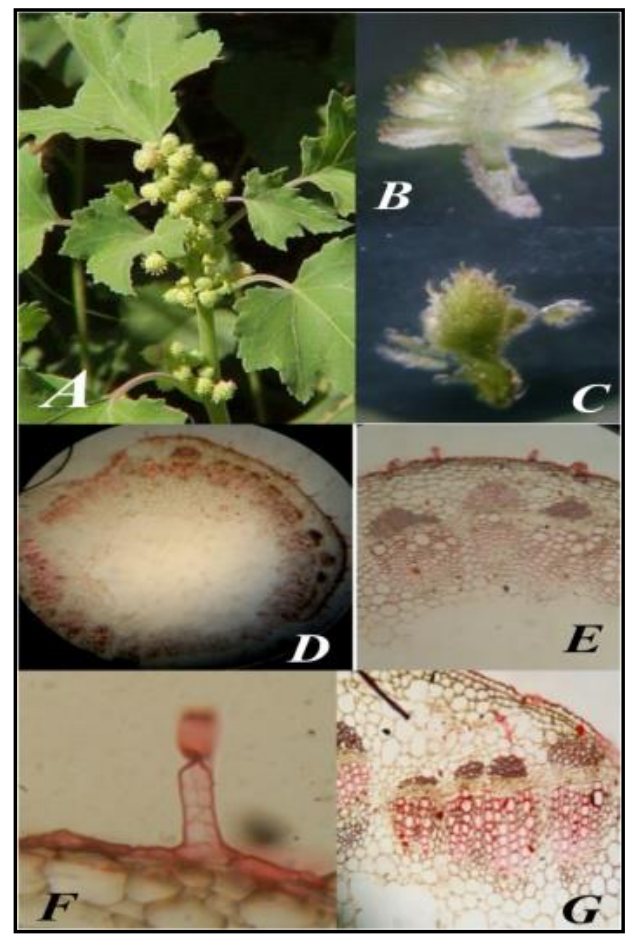

\section{Fig.13. Xanthium indicum}

A. Habit, B. Male Inflorescence, C. Female floret, D. Cross section of stem, E. Arrangement of vascular, F. Trichome, G. Structure of vascular bundle

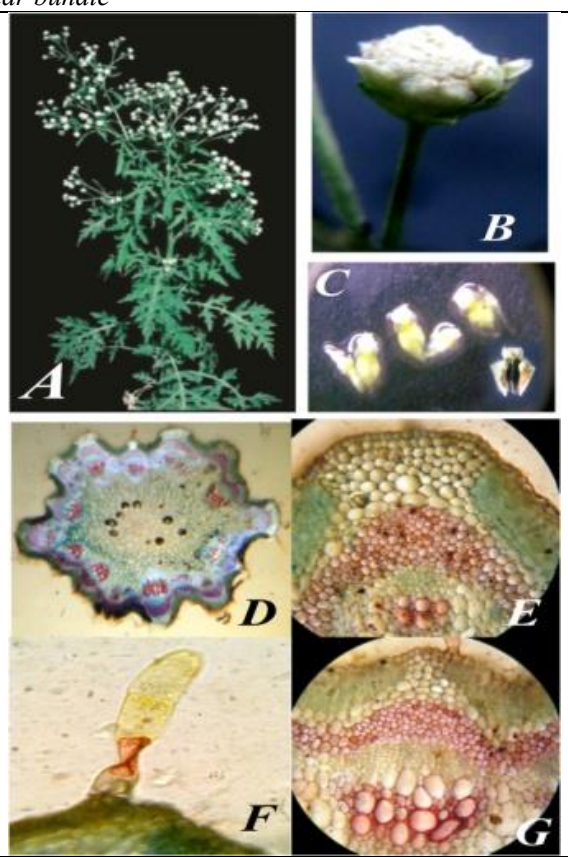

Fig. 15. Parthenium hysterophorus

A. Habit, B. Inflorescence, C, floret, D. Cross section of stem, $E$. Cortex \& vascular structure, F. Structure of Trichome, G. Vascular Bundle

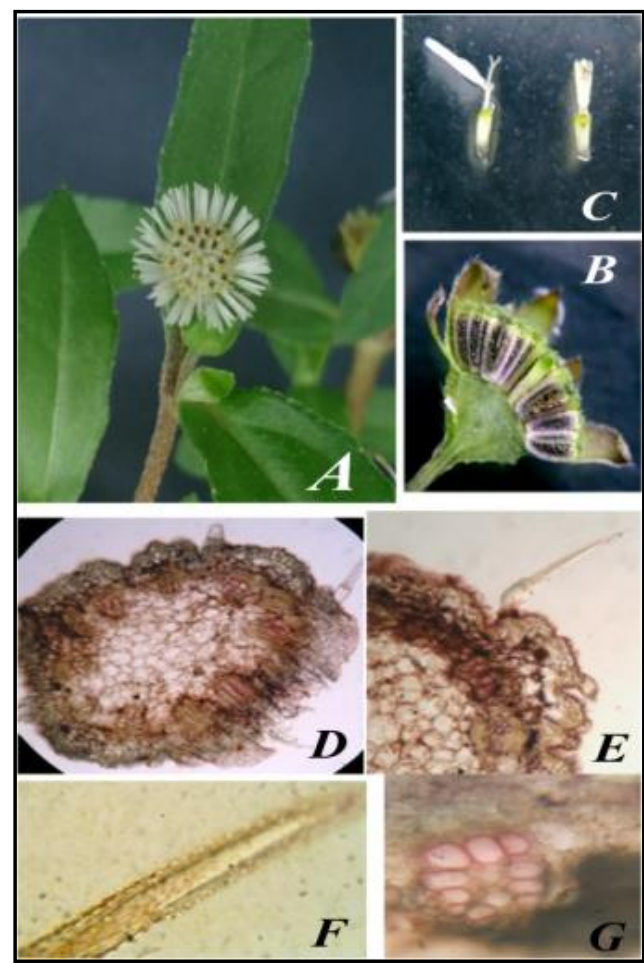

\section{Fig. 14. Eclipta alba}

A. Habit, B.L.S. of Inflorescence, C, Ray \& Disk floret, D. Cross section of stem, E. Cortex with Arenchymatous cell and trichome structure, F. Structure of trichome, G. Vascular bundles.

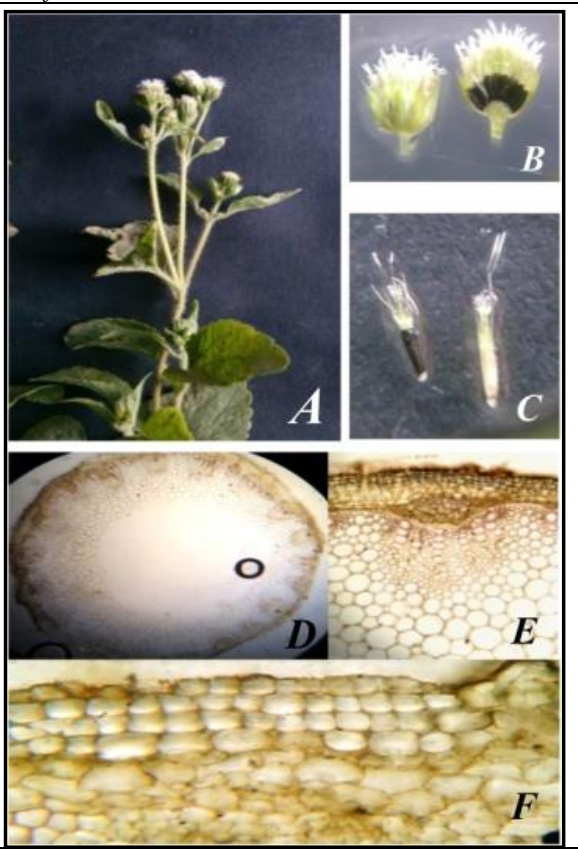

Fig.16. Ageratum conyzoides

A. Habit, B. Inflorescence, C, floret, D. Cross section of stem, E. Cortex $\&$ vascular structure, F. Structure of multilayered epidermis 